\title{
PENINGKATAN AKTIVITAS DAN HASIL BELAJAR FISIKA MELALUI PEMBELAJARAN FISIKA GASING PADA SISWA KELAS X-2 SMA NEGERI 1 PINANGSORI TAHUN PELAJARAN 2016/2017
}

\author{
Muhammad Ali \\ Guru Mata Pelajaran Fisika SMA Negeri 1 Pinangsori \\ Alipandan72@gmail.com
}

\begin{abstract}
Research action class it aims to find out if a top physics learning can improve student learning outcomes and activities. The research consists of two cycles are performed in class X-2 SMA Negeri 1 Pinangsori Central Tapanuli Regency who numbered 33 students. The characteristics of this class have a liveliness and low learning outcomes than classroom X others. Indicators of success for the liveliness of the students at least $75 \%$, and indicators of the results of the study classical at least $85 \%$ of the number of students who take the test. During the research showed an increase in the activities and achievements of student learning of the cycle I to cycle II. On cycle I nthe average ilai psychomotor students end of the cycle I of 75.85 became 79.26 end cycle II, the affective value of scientific attitude on cycle I with an average of 78.03 and rose to 80.74 on cycle II. Analysis of the cognitive learning of students obtained through exam results per cycle is done per cycle. Improvement of cognitive learning results seen from the average value obtained before students cycle 65 ketuntasan with $31 \%$, end of cycle I average of 73.52 with ketuntasan $63.64 \%$ and the end of sklus II becomes 78, 18 with ketuntasan $87.88 \%$. From the results of the research, it can be concluded that the application of learning physics top can increase the activity and results of the study physics in grade students X-2 SMA Negeri 1 Pinangsori.
\end{abstract}

Keywords: activity, the results of the study and a top Physics.

\begin{abstract}
Abstrak
Penelitian tindakan kelas ini bertujuan untuk mengetahui apakah pembelajaran fisika gasing dapat meningkatkan aktivitas dan hasil belajar siswa. Penelitian ini terdiri dari 2 siklus dilakukan di kelas X-2 SMA Negeri 1 Pinangsori Kabupaten Tapanuli Tengah yang berjumlah 33 siswa. Karakteristik kelas ini memiliki keaktifan dan hasil belajar yang rendah dibanding kelas X lainnya. Indikator keberhasilan untuk keaktifan siswa setidak-tidaknya $75 \%$, dan indikator hasil belajar klasikal sekurang-kurangnya $85 \%$ dari jumlah siswa yang mengikuti tes. Selama penelitian menunjukkan adanya peningkatan aktifitas dan hasil belajar siswa dari siklus I ke siklus II. Pada siklus I nilai rata-rata psikomotorik siswa diakhir siklus I sebesar 75,85 menjadi 79,26 diakhir siklus II, nilai afektif sikap ilmiah pada siklus I dengan rata-rata 78,03 dan naik menjadi 80,74 pada siklus II. Analisis belajar kognitif siswa diperoleh melalui hasil ujian per siklus yang dilakukan setiap siklus. Peningkatan hasil belajar kognitif terlihat dari nilai rata-rata yang diperoleh siswa sebelum siklus 65 dengan ketuntasan $31 \%$, diakhir siklus I ratarata sebesar 73,52 dengan ketuntasan $63,64 \%$ dan diakhir sklus II menjadi 78,18 dengan ketuntasan $87,88 \%$. Dari hasil penelitian, maka dapat disimpulkan bahwa penerapan pembelajaran fisika gasing dapat meningkatkan aktivitas dan hasil belajar fisika pada siswa kelas X-2 SMA Negeri 1 Pinangsori.
\end{abstract}

Kata kunci: Aktivitas, Hasil Belajar dan Fisika Gasing.

PeTeKa (Jurnal Penelitian Tindakan Kelas dan Pengembangan Pembelajaran) $\mid 82$ 
PeTeKa (Jurnal Penelitian Tindakan Kelas dan Pengembangan Pembelajaran)

Vol 1 No 2 Tahun 2018 Hal 82-87

\section{PENDAHULUAN}

Rendahnya hasil belajar siswa pada mata pelajaran Fisika di SMA Negeri 1 Pinangsori menjadi pemikiran bagi guru fisika. Rendahnya hasil belajar fisika ini dapat dilihat dari rendahnya persentase ketuntasan belajar siswa secara klasikal maupun sedikitnya siswa yang mendapat nilai bagus dalam setiap ulangan harian. Ketuntasan belajar siswa secara klasikal hanya berkisar $30 \%$ dan siswa yang mendapat nilai ulangan di atas 75 (untuk rentang nilai 0 - 100). Tentu kondisi ini masih jauh dari yang digariskan kurikulum yaitu ketuntasan belajar secara klasikal minimal $85 \%$. Kriteria Ketuntasan Minimum (KKM) mata pelajaran fisika yang ditetapkan sekolah adalah 75 , yaitu hanya $31 \%$ siswa yang mendapat nilai lebih besar atau sama dengan 75 dengan rata-rata berkisar 65

Rendahnya hasil belajar fisika siswa tersebut mengindikasikan ada something wrong dalam pembelajarannya. Dari hasil studi pendahuluan yang penulis lakukan dengan mewawancarai beberapa siswa SMAN 1 Pinangsori didapatkan keluhan siswa sebagai berikut: (1) materi terlalu banyak sedangkan waktu tatap muka hanya dua jam pelajaran perminggu; (2) guru fisika dianggap momok sehingga dalam pembelajarannya siswa tegang yang justru mengganggu konsentrasi belajar dan tidak menyenangkan; (3) jarang dilakukan praktikum sehingga siswa hanya membayangkan konsep-konsep abstrak yang sulit dipahami; (4) terlalu banyak rumus yang harus dihafalkan; (5) sebenarnya banyak materi yang belum jelas tetapi malu dengan temantemanya kalau mau menanyakan pada guru; (6) pembelajaran fisika monoton dan membosankan; dan (7) siswa mudah menyerah ketika menghadapi problem yang sulit dipecahkan karena tidak ada/jarang teman yang mau diajak berdiskusi. Sedangkan dari hasil wawancara dengan teman sejawat dalam forum MGMP fisika diperoleh keluhan guru sebagai berikut; (1) materi terlalu banyak sedangkan waktu tatap muka hanya empat jam pelajaran perminggu; (2) minat belajar fisika siswa rendah; (3) penguasaan materi tertentu para guru belum mantap; (4) guru kesulitan menentukan metode pembelajaran; (5) persiapan mengajar guru masih kurang; (6) siswa pasif sehingga pembelajaran hanya berlangsung satu arah.

Selama proses pembelajaran siswa seharusnya ikut terlibat secara langsung agar siswa memperoleh pengalaman dari proses pembelajaran hal ini sesuai pendapat baik (Mulyasa, 2013) yang menyatakan bahwa pembelajaran pada hakekatnya adalah proses interaksi antar peserta didik dengan lingkungannya, sehingga terjadi perubahan perilaku ke arah yang lebih.

Pembelajaran

fisika

menekankan pada pemberian pengalaman untuk mengembangkan kompetensi agar siswa mampu menjelajahi dan memahami alam sekitar secara ilmiah. Pendidikan fisika diarahkan untuk "mencari tahu" dan "berbuat" sehingga dapat membantu siswa memperoleh pemahaman yang lebih mendalam tentang alam sekitar (Koes, 2003)

Mata pelajaran fisika adalah salah satu mata pelajaran dalam rumpun sains, yang mengembangkan kemampuan berpikir analitis induktif dan deduktif dalam menyelesaikan masalah yang berkaitan dengan peristiwa alam sekitar. Fisika merupakan ilmu pengetahuan yang mempelajari gejalagejala alam dan interaksi didalamnya. 
Dalam pelaksanaannya, metode ceramah yang merupakan metode konvensional masih mendominasi dalam proses pembelajaran fisika. Metode ceramah hanya mengutamakan produk atau hasilnya saja. Padahal dalam pembelajaran fisika, proses dan produk sama pentingnya serta tidak dapat dipisahkan. Oleh karena itu, penggunaan metode dan pendekatan pembelajaran yang tepat dan bervariasi diharapkan akan meningkatkan aktivitas belajar siswa, dan dengan meningkatnya aktivitas selama pembelajaran, diharapkan dapat meningkatkan hasil belajar siswa. Hal ini sesui dengan pendapat Bloom (1981) dalam Depdiknas (2007) menyatakan bahwa proses belajar menyangkut tiga domain yaitu domain kognitif, afektif dan psikomotor.

Guru dapat meningkatkan aktivitas anak didiknya melalui pembelajaran yang berbasis laboratorium dan penyelidikan. Untuk kepentingan ini salah satu metode pembelajaran yang sesuai adalah ipembelajran fisika gasing (gampang asyik dan menyenangkan). Fisika Gasing merupakan metode pembelajaran Fisika yang dikenalkan oleh Profesor Yohanes Surya yang mengacu pada suatu cara yang mudah artinya tidak terpaku pada matematisnya tetapi penekanan pada konsep, Asyik karena siswa selalu ingin mempelajari karena tertarik dan menyenangkan karena dilaksanakan dengan kegiatan yang menyenangkan.

Untuk terlaksananya kegiatan pembelajaran fisika gasing ini, peneliti menggunakan model pembelajaran di laboratorium dengan harapan antara siswa terjadi interaksi aktif.

Kenyataan yang ada di lapangan, guru menggunakan pembelajaran konvensional (ceramah). Siswa hanya mendengar dan mencatat.
Alasan klasik mengapa guru menggunakan pembelajaran konvensional adalah : terbenturnya oleh waktu tatap muka di kelas, kesulitan untuk menyusun bahan pelajaran yang menggunakan pendekatan yang menarik, sarana dan prasarana yang kurang mendukung. Alasan tersebut menjadikan guru lebih memilih metode ceramah daripada metode lain.

Bertolak dari kenyataan bahwa banyak siswa memiliki tingkat keaktifan belajar yang rendah seperti siswa banyak terdiam sebagai pendengar dan mencatat, pembelajaran kuarng menari, hanya terpaku kepada matematid daripada konsepnya dan pada akhirnya hasil belajar siswa sangat rendah, maka saya sebagai seorang guru ingin mengubah cara pembelajaran fisika dengan memberikan aktivitas yang lebih bagi siswa melalui pembelajaran fisika gasing.

\section{METODE}

Penelitian ini merupakan penelitian tindakan kelas (Classroom Action Research) sebanyak dua siklus dan tiap siklus terdiri dari empat tahap yaitu perencanaan, pelaksanaan, pengamatan, dan refleksi. Penelitian tindakan kelas (PTK) ini dilaksanakan pada bulan Juli sampai dengan bulan Desember 2016.

Aktivitas siswa yang diamati dengan menggunakan lembar observasi afektif dan psikomotorik, sedangkan aktivitas guru berupa lembar observasi kelas untuk kegiatan guru. untuk mengukur afektif siswa dan kemampuan kognitif dengan isntrumen tes yang disusun dalam penelitian ini berupa soal pilihan ganda. 
PeTeKa (Jurnal Penelitian Tindakan Kelas dan Pengembangan Pembelajaran)

Vol 1 No 2 Tahun 2018 Hal 82-87

\section{HASIL DAN PEMBAHASAN}

Hasil peningkatan aktivitas belajar diperoleh berdasarkan lembar observasi, yaitu :

1. Pengamatan psikomotorik diperoleh melalui pengamatan langsung ketika siswa mengikuti kegiatan pembelajaran data sebagai berikut :

Tabel 1: Hasil Belajar Psikomotorik

\begin{tabular}{lcc}
\hline \multirow{2}{*}{ Uraian } & \multicolumn{2}{c}{ Nilai Psikomotorik } \\
& Siklus I & Siklus II \\
\hline Nilai tertinggi & 87,50 & 87,50 \\
Nilai terendah & 56,25 & 68,75 \\
Nilai rata-rata & 75,85 & 79,26 \\
Ketuntasan & $66,67 \%$ & $87,87 \%$ \\
\hline
\end{tabular}

Dari hasil analisis diperoleh bahwa pada siklus I, nilai rata-rata psikomotorik sebesar 75,85 dengan ketuntasan $65,67 \%$, karena kurang dari 75\% maka belum dikatakan tuntas secara klasikal. Pada siklus II, nilai ratarata psikomotoriknya sebesar 79,26, nilai tertinggi 87,50 nilai terendah 68,75 , dengan ketuntasan sebesar 87,87 $\%$. Sehingga hasil belajar psikomotorik pada siklus II dapat dikatakan tuntas secara klasikal. Hasil analisis penilaian afektif ( sikap ilmiah).

2. Penilaian afektif ( sikap ilmiah) dilakukan melalui pengamatan langsung ketika siswa mengikuti kegiatan pembelajaran. Hasil belajar afektif siswa sebagai berikut:

Tabel2: Hasil analisis penilaian afektif (sikap ilmiah)

\begin{tabular}{lcc}
\hline \multirow{2}{*}{ Uraian } & \multicolumn{2}{c}{ Jumlah Siswa (\%) } \\
& Siklus I & Siklus II \\
\hline Nilai Teringgi & 89,29 & 89,29 \\
Nilai Terendah & 60,71 & 64,29 \\
Nilai rata-rata & 79,03 & 80,74 \\
\hline
\end{tabular}

\begin{tabular}{l}
\hline Ketuntasan $69,70 \quad 90,90$ \\
\hline Dari tabel diatas dapat diketahui \\
bahwa kegiatan siklus I, siswa yang \\
memilki kemampuan afektif sikap \\
ilmiah rata-rata 79,03, tertinggi 89,29 \\
dan terendah 60,71 dengan ketuntasan \\
$69,70 \%$. Sedangkan siklus II rata-rata \\
80,74 , tertinggi 89,29 dan terendah \\
64,29 dengan ketuntasan $90,90 \%$.
\end{tabular}

3. Hasil Belajar kognitif siswa diperoleh dari tes hasil belajar. Nilai serta jumlah siswa yang tuntas belajar dapat dilihat pada tabel berikut ini.

Tabel 3: Hasil belajar tes kognitif siswa

\begin{tabular}{lccc}
\hline \multirow{1}{*}{ Uraian } & \multicolumn{3}{c}{ Nilai kognitif } \\
& Sebelum & Siklus & Siklus \\
& Siklus & I & II \\
\hline Nilai tertinggi & 80 & 84 & 88 \\
Nilai terendah & 45 & 56 & 68 \\
Nilai rata-rata & 65 & 73,52 & 78,16 \\
Ketuntasan (\%) & 31 & 63,64 & 87,88 \\
\hline
\end{tabular}

Dari hasil analisis belajar kognitif siswa yang disajikan pada tabel 3 dapat dilihat bahwa sebelum diterapkan pembelajaran fisika gasing yaitu nilai rata-rata ujian harian adalah 65 , nilai tertinggi 80 , dan nilai terendah 45 dengan ketuntasan $31 \%$, setelah diberikan pembelajaran fisika gasing mengalami peningkatan yaitu pada siklus I ( dua pertemuan) diperoleh nilai rata-rata ujian menjadi 73,52 , nilai tertinggi 84 dan nilai tertendah 56 dengan ketuntasan 63,64\%. Pada siklus II ( dua pertemuan) nilai rata-rata ujian sebesar 78,18 nilai tertinggi 88 dan nilai terendah 68, dengan ketuntasan 87,88\%.

Proses pembelajaran pada siklus I dengan pembelajaran fisika gasing diperoleh nilai rata-rata aktivitas psikomotorik sebesar 75,85 dengan ketuntasan klasikal 66,67\%. Sebagai tolak ukur keberhasilan, siswa belum 
dikatakan tuntas karena kurang dari $75 \%$ dari jumlah yang mengikuti tes.

Hasil belajar psikomotorik yang belum tuntas dikarekarenakan beberapa hal seperti, (1) masih ada siswa yang kurang terbiasa untuk melakukan kerja ilmiah atau kegiatan laboratorium sehingga belum memahami apa yang diharapkan melalui kegiatan percobaan; (2) ada sebagian siswa yang kurang bisa mengkomunikasikan data hasil percobaan. Sedangkan aktivitas afektif sikap ilmiah siswa, pada siklus I diperoleh nilai rata-rata 78,03 dan ketuntasan klasikal 69,70\%. Pada siklus I persentase jumlah siswa yang minatnya sangat baik sebesar $15,2 \%$ atau sebanyak 5 siswa, baik sebesar $69,7 \%$ atau sebaanyak 23 siswa, cukup $12,2 \%$ atau sebanyak 5 siswa, dan kurang $0 \%$.

Untuk hasil tes kognitif siswa pada siklus I, nilai rata-rata 73,52 dengan ketuntasan 63,64\%. Hasil belajar kognitif siswa pada siklus belum dikatakan tuntas karena siswa yang mendapatkan nilai minimal 75 (batas KKM) masih kurang dari 85\%. Perolehan ketuntasan belajar siswa secara klasikal yang belum memenuhi indikator yang telah ditetapkan. Hal ini disebabkan dari keaktifan siswa yang kurang optimal, selain itu guru kurang menguasai pembelajaran yang dapat dilihat dari hasil pengamatan kegiatan guru. Sehingga siswa masih enggan untuk bertanya pada guru jika mengalami kesulitan. Siswa kurang tertib dalam pengamatan karena belum mempelajari isi lembar kerja siswa/LKS yang akan dilakukan, saat diskusi jika ada siswa yang berpendapat kurang sesuai siswa yang lain akan berkomentar yang tidak baik. Sesuai dengan pendapat Hamalik (2005) yang menyatakan bahwa belajar adalah berbuat sendiri akan mengembangkan seluruh aspek pribadi siswa secara integral. Dalam setiap kegiatan belajar siswa selalu menampakkan keaktifan baik dari kegiatan fisik yang mudah diamati sampai kegiatan psikis yang sulit untuk diamati.

Berdasarkan hasil analisis data di atas maka perlu adanya perbaikan dalam proses pembelajaran selanjutnya yaitu guru harus berusaha mengelola kelas dengan baik, guru harus memperbaikai cara-cara memotivasi siswa untuk dapat menjawab pertanyaan dan mengungkapkan pendapat. Selain itu guru harus membimbing siswa dalam pengamatan dan diskusi sehingga siswa bisa terarah dengan baik. Guru juga harus berusaha menguasai pembelajaran fisika supaya proses pembelajaran dapat berlangsung sesuai dengan tujuan pembelajaran. Guru dapat membuat suasana pembelajaran yang lebih menyenangkan dan membuat siswa lebih banyak terlibat pada saat pembelajaran.

Pada Siklus II merupakan perbaikan kelemahan pada siklus I, ditekankan pada perbaikan cara-cara belajar, penguasaan cara mengajar, penyesuaian materi pelajaran dan mengurangi hambatan yang dihadapi siswa dengan memberikan lembar kerja siswa sebelum dilakukan kegiatan belajar mengajar agar dapat dipelajari sebelumnya. Cara yang digunakan guru dalam pelaksanaan pengajaran yaitu kelompok belajar praktikum jumlahnya anggotanya diperkecil 4-5 siswa. Pencapaian hasil belajar siswa tersebut telah memenuhi target yang telah ditetapkan untuk indikator jika dibanding dengan hasil belajar pada siklus I dan sebelum tindakan.

Dalam proses pembelajaran terjadi peningkatan jumlah siswa yang aktif mengajukan pertanyaan, menjawab pertanyaan, dan mereka juga sudah melakukan pengamatan dengan tertib dan baik dengan tepat waktu. 
PeTeKa (Jurnal Penelitian Tindakan Kelas dan Pengembangan Pembelajaran)

Vol 1 No 2 Tahun 2018 Hal 82-87

Dalam observasi terlihat kerjasama kelompok juga menunjukkan peningkatan. Peningkatan banyaknya siswa yang terlibat aktif selama proses pembelajaran tersebut merupakan salah satu indikator yang menunjukkan bahwa motivasi siswa untuk belajar juga semakin meningkat. Meningkatnya motivasi siswa maka tujuan pembelajaran seperti yang tercantum dalam tujuan pembelajaran khusus akan tercapai. Pencapaian hasil belajar siswa sudah sesuai dengan yang diharapkan tidak lepas dari peran guru dalam proses pembelajaran. Karena guru merupakan salah satu komponen yang mempengaruhi hasil belajar siswa.

\section{SIMPULAN}

Berdasarkan hasil penelitian dan obesrvasi, serta analisis data yang telah diuraikan dapat disimpulkan Melalui pembelajaran fisika gasing untuk pokok pembahasan Hukum Ohm, Hukum Khirchoff, suhu dan kalor dapat meningkatkan aktivitas dan hasil belajar fisika pada siswa kelas X-2 SMA Negeri 1 Pinangsori.

Analisis peningkatan aktivitas siswa diperoleh melalui analisis psikomotorik, afektif (sikap ilmiah) serta kegiatan guru yang mendukung dalam proses pembelajaran. Peningkatan aktivitas dapat terlihat dari : Nilai rata-rata psikomotorik siswa diakhir siklus I sebesar 75,85 menjadi 79,29 diakhir siklus II, Nilai afektif (sikap ilmiah) siswa siklus I rata-rata 78,03 dan miningkat di akhir siklus II sebesar 80,74 dan Nilai kognitif siswa diperoleh melalui hasil ujian per siklus yang dilakukan setiap siklus. Peningkatan hasil belajar kognitif terlihat dari nilai rata-rata yang diperoleh siswa sebelum siklus 65 dengan ketuntasan $31 \%$, diakhir siklus I dengan nilai rata-tata sebesar 73,53 dengan ketuntasan $63,64 \%$ dan diakhir sklus II menjadi rata-rata 78,18 dengan ketuntasan 87,88\%.

\section{DAFTAR PUSTAKA}

Depdiknas 2007. Belajar dan Berkarya. Jakarta : Depdiknas.

Hamalik, Oemar. 2005. Proses Belajar Mengajar. Jakarta : PT Bumi Aksara.

Koes H, Supriyono. 2003. Strategi Pembelajaran Fisika. Bandung : JICA.

Mulyasa, E. 2003. Kurikulum Berbasis Kompetensi, Konsep, Karakteristik dan Implementasi. Bandung : PT Remaja Rosda Karya. 